\title{
PROBLEMS OF THE PROFESSIONAL SELF- DETERMINATION OF MODERN SENIOR PUPILS
}

\author{
Danylenko G.N., Shvets A.N.
}

\section{ПРОБЛЕМИ ПРОФЕСИЙНОГО САМОВИЗНАЧЕННЯ ОО О СУЧАСНИХ СТАРШОКЛАСНИКІВ}

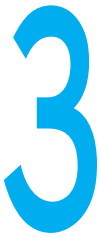

ДАНИЛЕНКО Г.М., ШВЕЦЬ А.M.

ДУ «Інститут

охорони здоров'я дітей та підлітків

$\mathrm{HAMH} »$

м. Харків

УДК $613.955-$

373.549

Ключові слова: підлітки,

професійна

орієнтація,

професійне

самовизначення професія. кожним роком проблема професійного самовизначення учнівської молоді набуває все більшої актуальності й істотно впливає на соціальний та економічний розвиток держави, освіту, самореалізацію, особистісний розвиток кожної молодої людини окремо. Сучасне суспільство з розвитком ринкових відносин висуває нов вимоги до освіти і професійного самовизначення молоді. У зв'язку з цим виникла потреба у людях, здатних до саморозвитку, до прийняття нестандартних рішень, до вміння орієнтуватися і бути конкурентоспроможними на ринку праці. Все це веде до змін не тільки у сфері професійної підготовки підлітків, а й на етапі вибору професії, який починається вже на шкільному рівні освіти [5, 12].

Багато шкіл успішно вирішують завдання предметної підготовки випускників до здачі ЗНО і вступу до вищих навчальних закладів. Однак орієнтація школяра на активне включення у процес професійного самовизначення у масовій освітній практиці виражається слабко. Найчастіше спостерігається слабкий рівень профорієнтаційної роботи у школах; недостатнє знання вчителями, учнями та їхніми батьками сучасного ринку освітніх послуг і ринку праці; дефіцит фахівців для реалізації профільного навчання та професійної орієнтації [1, 10].

Нинішня ситуація призвела до виникнення суперечності між потребою сучасного, швидко мінливого суспільства у соціально зрілих, активних і самостійних випускниках загальноосвітньої школи і недостатньою розробленістю науково-методичного забезпечення діяльності дорослих суб'єктів освіти (керівники школи, вчителі та батьки) щодо забезпечення таких високих вимог [2].

Сучасний розвиток старшокласника змінює характер його спілкування і діяльності, свідомості і мислення, а також структуру педагогічної взаємодії з ним, форми організації та принципи відбору змісту освіти, пропоновані на шкільному етапі. Професійне самовизначення старших школярів - це свідомий і самостійний вибір професії і вишу на основі розвитку здібностей, інтересів, професійної придатності та інших суб'єктивних чинників в умовах спеціально і цілеспря-
ПРОБЛЕМЫ ПРОФЕССИОНАЛЬНОГО САМООПРЕДЕЛЕНИЯ СОВРЕМЕННЫХ

СТАРШЕКЛАССНИКОВ

Даниленко Г.Н., Швец А.Н.

ГУ «Институт охраны здоровья детей и подростков HАMH», Г. Харьков

Цель работы. В статье раскрыто понятие и содержание профессионального самоопределения в подростковом возрасте, приведены результаты исследования процесса формирования профессионального самоопределения старшеклассников. В результате проведенного исследования среди учащихся 14-15 лет 9-х классов общеобразовательных школ Украины было установлено, что при равных условиях планирования своего профессионального пути дальнейшее поэтапное самоопределение будущей специальности обусловлено не только психологической готовностью к сознательному выбору, но и состоянием здоровья, и уровнем психофизиологической адаптации

Объекты и методы исследования. В исследовании принимали участие 982 ученика общеобразовательных школ Украины 14-15 лет (493 юноши и 489 девушек). С целью изучения уровня сформированности профессиональной готовности проводилось анкетирование по разработанным в ГУ «Институт охраны здоровья детей и подростков НАМН Украины» опроснику, который содержал альтернативные и ранжированные по степени проявлений признаков вопросы относительно учебной деятельности, планируемого образования, определения профессионального будущего и профинформированности. Статистическая обработка материалов исследования осуществлялась с помо- щью пакетов MS Excel, SPSS-17.

Результаты исследования показали, что профессиональные намерения 9-классников являются ключевой характеристикой для решения задачи выбора вуза и будущей профессиональной деятельности. Но у большинства школьников эти намерения противоречивы в силу объективных причин, обусловленных отсутствием возможности школы в организации и проведении профориентационной деятельности. Достигнутый уровень профессионального самоопределения 9-классников отличается в зависимости от их половой принадлежности. Девушки чаще демонстрируют более высокие показатели профессионального самоопределения. Возрастные различия девятиклассников не влияют на процесс профессионального самоопределения. Главными источниками информации о профессиональном будущем для школьников есть родители, Интернет, учителя и школьные психологи, одноклассники и друзья. Радио, телевидение, книги, медработники учебного заведения по вопросам выбора профессии не оказывают существенного влияния на уровень профессионального самоопределения выпускников 9-х классов.

Проведенное анкетирование является достаточным для анализа профессиональной ориентации учащихся. При этом профессиональный выбор школьников формируется под влиянием многих факторов, которые корректируют и желание, и стремление. Поэтому проведение исследований по профориентации требует комплексного подхода.

Ключевые слова: подростки, профессия, профессиональная ориентация, профессиональное самоопределение.

ㄷ Даниленко Г.М., Швець А.М. СТАТТЯ, 2017. 
PROBLEMS OF THE PROFESSIONAL SELFDETERMINATION OF MODERN SENIOR PUPILS Danylenko G.N., Shvets A.N.

SI "Institute for Protection of Children's and Teenagers' Health, NAMS", Kharkiv

Objective. In the article we disclosed a concept and a content of the professional self-determination in the teenagers. The results of the study of the formation of professional self-determination in the senior pupils are presented in it. As a result of the study performed among the 9-th grade pupils of the secondary schools of Ukraine aged 14-15 years old, we determined that under equal conditions of the planning of the professional activity the further phased self-determination of the future specialty was stipulated not only by the psychological readiness for conscious choice but also by the state of health and the level of psychophysiological adaptation.

Materials and methods. 982 pupils of secondary schools of Ukraine aged 14-15 years old ( 493 boys and 489 girls) took part in the study. To study the level of the formation of professional readiness, we performed a survey with the help of the questionnaire, developed by the SI "Institute for Protection of Children's and Teenagers' Health, NAMS" which contained both alternative and ranked questions about the educational activity, planned education determination of the professional future, and professional awareness.

Statistical processing of study materials was carried out with the help of MS Excel and SPSS-17.

Results. The results of the study showed that professional intentions of the 9-graders are a key feature for the solution of the problem of higher school choice and future vocational activity. These intentions are contradictory in the most students due to the objective reason, such as a lack of school opportunity in the organization of the vocational guidance.

The achieved level of the professional self-determination of the 9-graders differs depending on gender. The girls demonstrated higher indices of their professional selfdetermination. Age differences of the 9-graders don't affect the process of the professional self-determination. The parents, Internet, teachers and school psychologists, classmates and friends are the main sources of the information about professional future. Radio, television, books, medical staff of the educational institution don't affect significantly the choice of the profession and the level of professional self-determination in the 9-graders.

Performed survey is sufficient for the analysis of the vocational guidance of the students. The professional choice of the students is formed under the effect of many factors which adjust both desire and aspiration. Therefore the studies on the vocational guidance require an integrated approach.

\section{Keywords: teenagers, vocational guidance,} professional self-determination, profession. мовано організованої системи профорієнтації [3, 11].

Критерії оцінки результативності реалізації програми профорієнтації старшокласників, що сприяє їхньому професійному самовизначенню - це задоволеність професійних намірів і потреб старших школярів; готовність підлітків до прийняття рішення щодо вибору професії та побудови індивідуального плану майбутньої освіти і професійного самовизначення [4].

Профорієнтаційна робота зі школярами проявляється через вміння ставити цілі і планувати профорієнтаційну роботу з урахуванням потреб ринку праці; вміння враховувати психологічні особливості підліткового віку; вміння проектувати і здійснювати профорієнтаційні заходи 3 урахуванням професійних намірів школяра; вміння розробляти інформаційне і методичне забезпечення змісту і процесу вирішення профорієнтаційних завдань $[9,10]$.

Відомо, що у соціокультурному плані у нашій країні світ цінностей молоді, особливо школярів, надзвичайно суперечливий. Молоді люди не завжди можуть правильно орієнтуватися у соціальній дійсності. Їм необхідно надавати не лише інформаційну, психологічну, а й педагогічну допомогу на етапі вибору професії та подальшого шляху в освіті.
Специфіка проблем, пов'язаних з наданням допомоги старшим школярам у професійному самовизначенні, вимагає пошуку нових форм роботи 3 професійної орієнтації. Очевидною стає необхідність розробки і послідовної реалізації підходів, орієнтованих на пряме залучення школярів до вирішення власних проблем $[4,9]$.

Нині молоді люди більше орієнтовані на отримання освіти як такої, без урахування професії. Сформована ситуація викликає необхідність детального вивчення як самої системи профорієнтаційної роботи, так і безпосередніх учасників даного процесу. Актуальністю даного дослідження є виявлення рівня професійного самовизначення старшокласників, механізмів формування професійних уподобань, факторів, що впливають на вибір професійної діяльності та дозволяють оцінити ефективність форм професійної орієнтації $[8,11]$.

Метою проведеного дослідження $є$ виявлення професійних уподобань учнів 9-х класів, мотиваційної обґрунтованості та критеріїв, що визначають вибір професії залежно від статі, інтересів та планів щодо майбутнього.

Матеріали та методи дослідження. Моніторинг виявлення рівня професійного самовизначення старшокласників проводився під час ком- плексного опитування підлітків у процесі шкільного навчання. У дослідженні брали участь 982 учня загальноосвітніх шкіл України 14-15 років (493 юнака та 489 дівчат). 3 метою вивчення рівня сформованості професійної готовності проводилося анкетування за розробленим у ДУ «Інститут охорони здоров'я дітей і підлітків АМН України» опитувальником, який містив альтернативні та ранжовані за ступенем проявів ознаки питання щодо навчальної діяльності, запланованої освіти, визначення професійного майбутнього та профінформованості. Статистична обробка матеріалів дослідження здійснювалася за допомогою пакетів MS Excel, SPSS- 17.

Результати досліджень та їx обговорення. Передбачається, що професійний вибір має бути зроблений на основі оцінки своїх здібностей і можливостей, престижу професії та її змісту, а також соціальноекономічної ситуації [6].

Для 9-класників актуальним є навчально-професійне самовизначення - усвідомлений вибір шляхів професійної освіти і професійної підготовки.

Освоєння цього рівня професійного самовизначення завдання профільного навчання на вищому рівні загальноосвітньої школи. Однак у тих випадках, коли 9-тикласники залишають школу після отри- 
мання неповної середньої освіти, завдання професійного самовизначення має вирішуватися у рамках допрофільної підготовки [2, 8].

Після закінчення 9-го класу випускник школи, якщо продовження навчання на вищому рівні не планується, повинен визначитися 3 майбутньою професійною діяльністю або обрати траєкторію отримання професійної освіти. Якщо отримання загальної освіти буде продовжено, то цей вибір може бути відкладеним до закінчення повної середньої школи. Однак необхідність такого ж (двонаправленого) вибору знову актуалізується після закінчення 11-го класу, коли слід заміряти рівень професійного самовизначення випускника і оцінювати ефективність профорієнтаційної роботи $[7,12]$.

у представленому аналізі емпіричними індикаторами рівня професійного самовизначення виступають зафіксовані в анкетах несуперечливі (однозначні, логічно вибудовані) набори відповідей 9-класників про планування майбутньої освіти (вища - магістр, вища - бакалавр, середня спеціальна, загальна середня), визначення з майбутньою професією та роль різних джерел отримання найважливішої інформації щодо професійного майбутнього [6, 7]

Аналіз результатів дослідження оцінки планування майбутньої освіти 9-класниками характеризується даними, зображеними на рисунках 1-3. Професійні інтереси школярів тісно пов'язані 3 вибором навчального закладу, в якому вони здобуватимуть освіту за обраною професією. Варіанти майбутнього навчання різні. 9-класники можуть продовжити навчання у школі або піти вчитися до середнього спеціального закладу. 3 наведених даних видно, що більшість 9-класників хоче продовжувати навчання у школі та планує вступати до вишу (вища магістр бажають отримати $45,42 \%$ та вища - бакалавр 35,84\%). 9-класників, які бажають стати магістрами, більше серед дівчат, ніж серед хлопців (різниця становить 14\%), а тих, хто бажає стати бакалаврами, більше серед юнаків, ніж серед дівчат (різниця становить $4,5 \%$ ). Загальну середню освіту також планують здобути 2,14\% школярів (серед них хлопців більше на 2,5\%, ніж дівчат), які ще не визначилися зі своїм майбутнім. Середню спеціальну освіту плануюсь здобути $16,60 \%$ школярів (серед них хлопців більше на 7\%, ніж дівчат).

Результати дослідження показали, що визначилися 3 вибором професії і роблять все для досягнення мети 59,16\% школярів, серед них хлопців більше, ніж дівчат на 7\% (рис. 4-6). 4,28\% учнів зробили свій професійний вибір, але нічого не роблять для досягнення мети, серед них хлопців більше, ніж дівчат на 4,5\%. 36,56\% 9-класників не мають уявлення, яку професію обрати, вважаючи, що мають час для вибору. Серед них дівчат більше, ніж хлопців на $11,5 \%$. Осіб, які не мають потреби вибору, у ході анкетування не виявлено.

Результати дослідження, 3 яких джерел 9-класники отримують найважливішу інформацію щодо професійного майбутнього, характеризуються даними, зображеними на рисунку 7. За результатами досліджень вибір професії

Рисунок 1

Діаграма розподілу даних планування майбутньої освіти 9-класниками

Діаграма розподілу даних планування майбутньої освіти 9-класниками (хлопці)

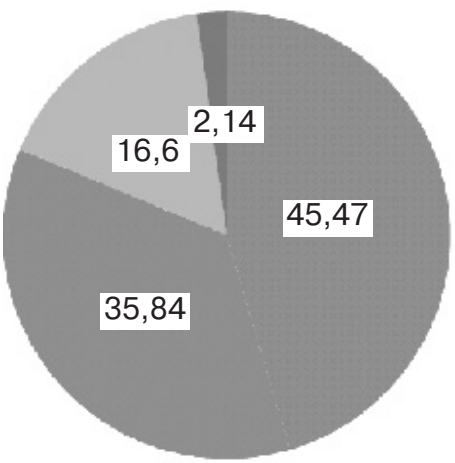

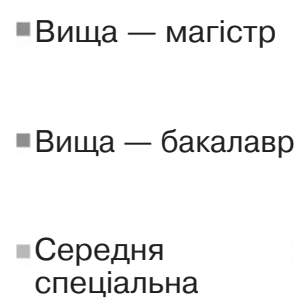

- Загальна середня

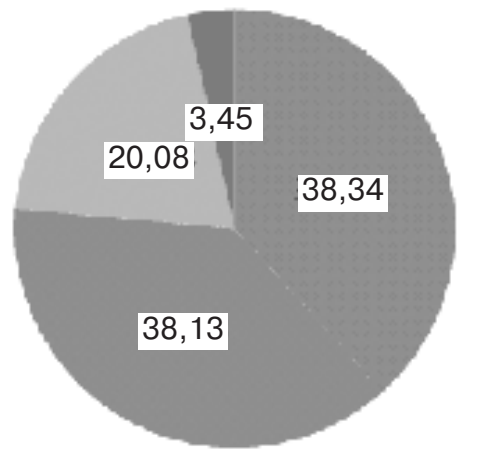

Вища - магістр

Вища бакалавр

Середня спеціальна

Загальна середня

Рисунок 3

Діаграма розподілу даних планування майбутньої освіти 9-класниками (дівчата)

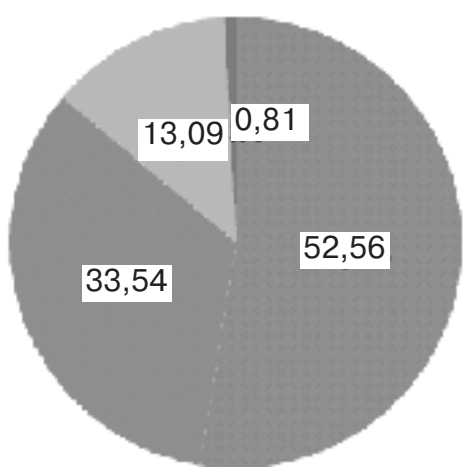

Вища -
магістр
Вища -
бакалавр
Середня
спеціальна
Загальна
середня

дi

Діаграма розподілу даних щодо вия

Рисунок 4 9-класниками 3 професійним майбутнім

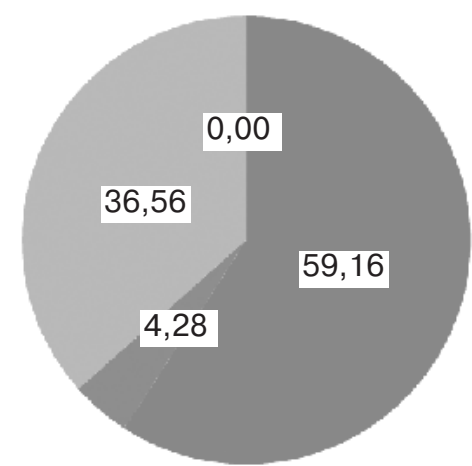

- Так, визначився роблю, що можу для досягнення

- Визначився, але нічого не роблю для досягнення

- Не визначився, ще $\epsilon$ час

- Не маю потреби 
залежить від батьків у 89,82\% школярів, серед них до поради батьків дівчата прислухаються більше, ніж хлопці на 5\%. Профорієнтаційну інформацію 3 Інтернету дістають 45,21\% підлітків, серед них Інтернетом користуються хлопці більше, ніж дівчата на 1\%. Вчителі і шкільні психологи допомагають визначитися у сфері отримання професійної освіти $32,08 \%$ учням, серед них педагогічними порадами користуються дівчата більше, ніж хлопці на $3 \%$.

За результатами дослідження під впливом однокласників та друзів вибір майбутньої професії здійснюють 19,35\% учнів, з них дружньою порадою користуються дівчата на 4\% більше, ніж хлопці.

3 радіо, телебачення та книжок про майбутню професійну діяльність дізнаються 11,20\% школярів, з них цими засобами інформації користуються дівчата на 4,5\% більше, ніж хлопці. освіти ще не означає однозначного вибору професії та можливих місць роботи.

Рівень самовизначення 9-класників загальноосвітніх шкіл невисокий.

Розподіл сформованості професійних уподобань не дозволяє судити про якість професійного вибору. Дослідження не показує, наскільки професійно-освітні плани старшокласників відповідають їхнім нахилам і можливостям самореалізації особистості, наскільки професійні наміри відповідають запитам роботодавців, можливостям надання освітніх послуг і затребуваності бажаних кваліфікацій на ринку праці.

\section{Висновки}

Результати дослідження показали, що професійні наміри 9-класників є ключовою характеристикою для вирішення завдання вибору вишу і майбутньої професійної діяльності. Але у більшості школярів ці наміри складаються досить суперечливо через об'єктивні причини, зумовлені передусім відсутністю можливості школи в організації і проведенні профорієнтаційної діяльності.

у роботі 3 підлітками слід приділяти увагу гендерним особливостям, професійним перевагам, специфіці вибору професійних уподобань.

Залежно від статевої приналежності 9-класників досягнутий рівень професійного самовизначення відрізняється. Дівчата частіше демонструють вищі показники професійного самовизначення.

Вікові відмінності дев'ятикласників не впливають на процес професійного самовизначення, очевидно, через невелику різницю у віці випускників 9-х класів.

Головними джерелами найважливішої інформації щодо професійного майбутнього $€$ батьки, Інтернет, вчителі, шкільні психологи, одноклас-
Рисунок 5

Діаграма розподілу даних щодо визначення 9-класниками 3 професійним майбутнім (юнаки)

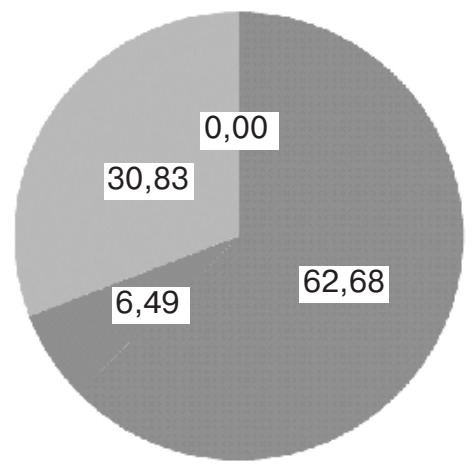

Пораду медпрацівників навчального закладу у визначенні $з$ професійною сферою прийняли 2,65\% підлітків, з них цією допомогою користуються хлопці більше, ніж дівчата на $0,5 \%$.

Також 3,97\% 9-класників отримали профорієнтаційну інформацію із інших джерел, 3 них хлопців більше, ніж дівчат на $0,5 \%, 2,14 \%$ підлітків, які професійно дезорієнтовані, 3 них хлопців більше, ніж дівчат на $0,5 \%$.

Відзначимо, що у логіці представленого аналізу самовизначення у професійній діяльності передбачається вибудовування певної освітньої траєкторії, тоді як самовизначення у сфері професійної

- Не визначився, ще $є$ час

100,0
- Так, визначився роблю, що можу для досягнення

"Визначився, але нічого не роблю для досягнення

- Не маю потреби

Діаграма розподілу даних щодо визначення 9-класниками з професійним майбутнім (дівчата)

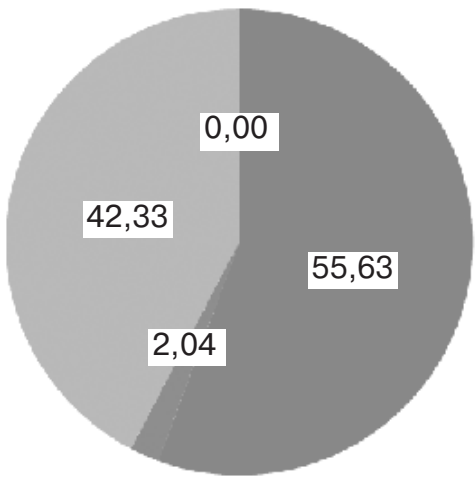

- Так, визначився роблю, що можу для досягнення

- Визначився, але нічого не роблю для досягнення

- Не визначився, ще $€$ час

- Не маю потреби

Рисунок 7

Діаграма розподілу даних щодо отримання найбільш важливої інформації про професійне майбутнє

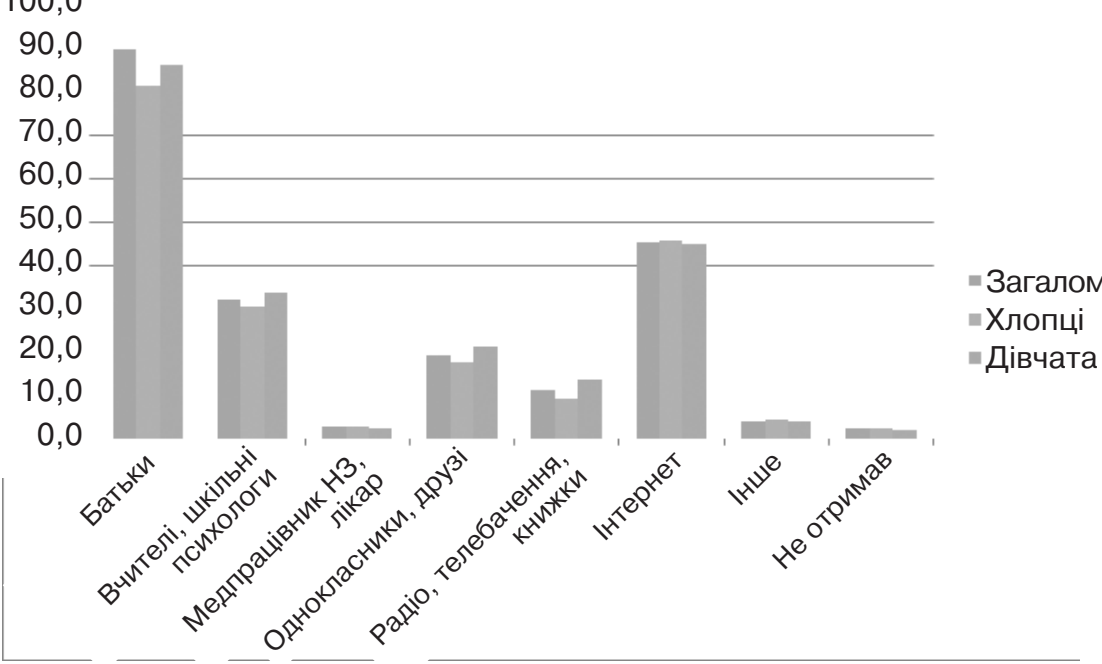


ники та друзі. Радіо, телебачення, книжки, медпрацівники навчального закладу з питань вибору професії істотно не впливають на рівень професійного самовизначення випускників 9-х класів.

Усвідомлений вибір професії, що виявляється у виборі форми і напрямку подальшого навчання, відбувається у дев'ятому класі (14-15 років), на основі такого вибору здійснюється його інструменталізація (через навчання у профільних класах, курси, репетиторство, додаткові заняття). У цьому віці старшокласники більш сприйнятливі до психологічної роботи з побудови професійного майбутнього.

При формуванні оптимального професійного самовизначення слід враховувати можливість здійснення професійного вибору за інтересами, усвідомлення своїх професійних нахилів, здібностей, індивідуальнопсихологічних особливостей адекватне уявлення про зміст майбутньої професійної діяльності.

Проведене анкетування $€$ самодостатнім для аналізу професійної орієнтації учнів. Але професійний вибір школярів формується під впливом багатьох факторів, які коригують і бажання, і прагнення. Тому проведення досліджень 3 профорієнтації потребує комплексного підходу.

ЛІТЕРАТУРА

1. Бесєдіна О.А.,

Кошакова Т.М., Даниленко Г.М. Проблеми погіршення стану здоров'я дітей та підлітків в умовах навчального закладу. Актуальные проблемы и основные направления развития профилактической науки и практики. Харьков, 2007. С. 51-55.

2. Донецкий А.М., Крылова Н.А. Профориентация населения важное условие эффективной занятости. Вестник ВГУ. 2011. № 1. C. 226-228.

3. Коренєв М.М. Основні проблеми медичного забезпечення дітей та підлітків. Актуальні проблеми організації медичного забезпечення дітей та підлітків. Харків, 2012. С. 20-24

4. Коренев Н.М., Немирова О.А., Булага Л.П. и др. Состояние здоровья подростков Украины. Проблеми мед. науки та освіти. 2005.

№ 4. С. 5-7.

5. Курик М.В., Кошакова Т.М. Запорука здоров'я дітей.

Наше здоров'я. 2010. № 4.

С. 6-8.

6. Медведева М.А., Шиян Н.И. Почему люди так редко работают по выбранной специальности. Наука, техника и образование. 2014. № 1.

C. 103-106

7. Парнов Д.А., Скоблина Н.А. Социально-педагогический компонент профессиональной ориентации школьников.

Социальная педагогика. 2011.

№ 6. С. 107-111.

8. Огнєв В.А., Галічева Н.О., Сокол К.М., Усенко С.Г., Федак Н.М., Рубінський М.Д. та ін. Соціально-психологічні особливості способу життя студентів та їхній вплив на здоров'я. Експериментальна і клінічна медицина. 2012. № 1. С. 164-169.

9. Попович А.Э., Омельченко С.A. К вопросу о профессиональном самоопределении выпускников общеобразовательных школ. Социальногуманитарные знания. 2011. № 2. C.169-177.

10. Файзрахманова А.Л., Чернявская А.П. Использование зарубежного опыта в профориентационной деятельности. Молодой ученый. 2013. № 8. С. 442-444.

11. Шубочкина Е.И., Иванов В.Ю. Оптимизация трудовой деятельности учащихся, работающих в свободное от учебы время. Материалы I Конгресса Российского общества школьной и университетской медицины и здоровья. Москва, 2008. С. 195 196.

12. Abele AE., Spurk D. The longitudinal impact of self-efficacy and career goals on objective and subjective career success. Journal of Vocational Behavior. 2009. Vol. 74, № 1. P. 53-62.

\section{REFERENCES}

1. Besedina O.A.

Koshakova T.M. and

Danilenko G.M. Problemy pohirshennia stanu zdorovia ditei ta pidlitkiv $v$ umovakh navchalnoho zakladu [Problems of the Deterioration of the Health State of Children and Teenagers under Conditions of the Educational Institution]. In : Aktualnye problemy i osnovnye napravleniia razvitiia profilak- ticheskoi nauki i praktiki [Actual Problems and Main Directions of the Development of Preventive Science and Practice]. Kharkiv; 2007: 51-55 (in Ukrainian).

2. Donetskiy A.M. and Krylova N.A. Proceedings of Voronezh State University. 2011; 1; 226-228 (in Russian).

3. Korenev M.M. Osnovni problemy medichnoho zabezpechennia ditei ta pidlitkiv [Main Problems of Medical Provision of Children and Teenagers]. In : Aktualni problemy organizatsii, medichnoho zabezpechennia ditei ta pidlitkiv [Actual Problems of the Organization of Medical Provision of Children and Teenagers]. Kharkiv; 2012: 2024 (in Ukrainian)

4. Korenev N.M., Nemirova O.A., Bulaga L.P. et al. Problemy medychnoi nauky ta osvity. 2005 ; 4 : 5-7 (in Russian).

5. Kurik M.V. and Koshakova T.M. Nashe zdorovia. 2010 ; 4 : 6-8 (in Ukrainian).

6. Medvedeva M.A. and Shiyan N.I. Nauka, tehnika i obrazovaniye. 2014 ; 1 : 103106 (in Russian).

7. Parnov D.A. and Skoblina H.A. Sotsialnaia pedagogika. $2011 ; 6$ : 107-111 (in Russian).

8. Ogniev V.A., Galicheva N.O., Sokol K.M., Usenko S.G. Fedak N.M., Rubinskyi M.D. et al. Eksperymentalna i klinichna medytsyna. $2012 ; 1$ : 164-169 (in Ukrainian).

9. Popovich A.E. and Omelchenko S.A. Sotsialnogumanitarnye znaniia. 2011 ; 2 . 169-177 (in Russian).

10. Fayzrakhmanova A.L. and Cherniavskaya A.P. Molodoy uchenyy . 2013 ; 8 : 442-444 (in Russian).

11. Shubochkina E.I. and Ivanov V.Yu. Optimizatsyia trudovoy deiatelnosti uchaschikhsia, rabotaiushchikh v svobodnoe ot ucheby vremia [Optimization of Work Activity of the Pupils in Leisure Time]. In : Materialy I Kongr. Ros. obschestva shkolnoy i universitetskoy meditsiny i zdorovia [Materials of the I Congress of the Russ. Society of School and University Medicine and Health]. Moscow ; 2008 : 195-196 (in Russian).

12. Abele A.E. and Spurk D. Journal of Vocational Behavior. 2009 ; 74 (1) : 53-62.

Надійшла до редакції 21.05.2017 